\title{
Organizational Storytelling Translated to Successful Business
}

\author{
Anne Eskola ${ }^{1}$ and Shab Hundal ${ }^{2}$ \\ ${ }^{1}$ JAMK University of Applied Sciences \\ Rajakatu 35 (Jyväskylä, Finland) \\ Email: anne.eskola [AT] jamk.fi \\ 2 JAMK University of Applied Sciences \\ Rajakatu 35 (Jyväskylä, Finland) \\ Email: shabnamjit.hundal [AT] jamk.fi
}

\begin{abstract}
In 2007, two friends decided to establish a new IT company, but not just another software company a phrase that later became one of their slogans. The Finnish IT company called Vincit has turned out to be a success story both financially and in terms of personnel and customer satisfaction. The company is known for its skillful use of media as a deliverer of their company story. This paper examines organizational storytelling through media. The empirical data was gathered between 2012 and 2019, and it is analyzed using narrative analysis focusing on the types of stories told and how they are narrated.
\end{abstract}

Keywords— storytelling, organizational story, management, qualitative research

\section{INTRODUCTION}

Knowledge has always resided in organizations, but only during the Information Age have organizations recognized knowledge or intellectual capital as a critical resource of the company (Cohen \& Prusak, 2001) that has an influence on organizational effectiveness and competitive advantage (Hannabuss, 2000). Storytelling is a traditional way of passing on knowledge and culture, but it has been seen as having less value in business organizations comparing to hard forms of knowledge that can be classified, categorized, calculated, and analyzed (Sole \& Wilson, 2002).

Only recently have organizations recognized that knowledge cannot always be completely abstracted into categorical and analytical forms; nor can it be conveyed in such forms (Sole \& Wilson, 2002). Earlier, organizational knowledge used to be created through a continuous dialogue between tacit and explicit knowledge (Nonaka, 1994), but now we are entering a third age of knowledge management in which the focus on tacit-explicit conversion is no longer adequate. Instead, there will be a new focus on the management of narrative, or story (Snowden, 2002).

Communication in organizations, in general, is important in its factual form (Marchiori \& Bulgacov, 2012), but it is also important in other, more emotional forms such as storytelling (Barker \& Gower, 2006; Boje, 2008; Denning, 2005; Gabriel, 2000) because storytelling is a powerful management tool (Savita, Hazwani \& Kalid, 2011) and “... the story can become a viral communication, being passed from mouth to mouth, up, down, around and external to the organization. It can grow with the telling, it can become a modern myth, it can cement a company's position and ultimately it can make the difference between success and failure" (Love, 2008).

For companies operating in knowledge-intensive product markets, such as IT companies, the significance of good reputation is particularly essential. This is because the pre-purchase evaluation of product quality is difficult, as the production process starts only after the purchase and there is always an asymmetry in information between sellers and buyers (Vendelø, 2016). Truth is important in storytelling because it defines how effectively the message of the story is conveyed (Barker \& Gowen, 2010). Indeed, an organization's success is increasingly attributable to soft forms of capital like its reputation (Post, 2004), and poor communication skills can create negative consequences in terms of lost business opportunities, lost productivity, and damage to reputation (Knotts \& Thibodeaux, 1992).

Current literature reflects the principle of a direct link between the use of organizational storytelling, heightened employee engagement, and improved reputation (Gill, 2011). In other words, employer communication predicts 
employee satisfaction, and storytelling is an important medium in building employer-employee relationships (McCarthy, 2008; Madlock, 2008). Therefore, all organizations, but especially knowledge-intensive ones, require as much attention to employee loyalty as customer loyalty (Gallicano, 2009; Pina e Cunha, 2002; Alvesson, 2001), since internal respect for the company brand often translates into a healthy reputation externally (Post, 2004).

Now that organizations have entered the third age of knowledge management and there will be a new focus on the management of organizational story, it is important to study narratives because our ordering of time and space in narrative forms constitutes one of the primary ways we use to construct meaning (Felluga, 2003). There are certain underlying narrative structures that remain constant, despite the apparently endless diversity of story forms and content (Pradl, 1984).

In this study we examine stories of a case company, a reputable Finnish information technology company called Vincit. The company is known for its very high employee and customer satisfaction, for its sound financial performance year after year, for the many prizes it has won at national and international levels, and for its unique use of stories as part of its collective identity construction as well as leadership practices. The company has also attracted media in an exceptional way to convey their organizational storyline, and the company declared in public that they do not use any financial resources for operations such as marketing. Instead, they are willing to tell their story on different occasions and in public media.

This paper aims at describing in detail how organizational storytelling can be used to convey the message a company wants to tell the world and help in building a successful business. We use a narrative approach, which is qualitative, subjective and interpretive by nature. but does not attempt to answer questions or predict future behaviours. The research tasks for the study are: 1) What thematic elements appear in organizational stories? 2) What are the purposes of organizational stories? and 3) How is a good organizational story constructed? The results will not be generalizable to other companies, but they reveal essential features of good organizational stories: their thematics, purposes and structures. The remainder of this article consists of five sections: a literature review, data and methodology descriptions, results, conclusions, and discussion.

\section{LITERATURE REVIEW}

Traditional management research considers organizations as machine-like, controllable mechanisms that need hierarchical management, leadership, and authority structures (Morgan, 2006; McDaniel \& Driebe, 2005) so that organization members can perform their tasks in a coordinated, efficient, and effective manner (Howell, 1997; Kerr \& Jermier, 1978). Prescribed rules and formalized control are supposed to simplify and clarify the organization's operations and lead to simple, well-defined, and predictable responses to a knowable world (Plowman, Solansky, Beck, Baker, Kulkarni \& Travis, 2007).

Many organizations today lean on traditional, hierarchical, managerialist orientation that is powerful in the production of physical products (Sohlberg, Czaplicka \& Lindblad, 2008; Bandura, 2002), but ill-suited to a knowledgeoriented economy (Uhl-Bien, Russ \& McKelvey, 2007; Cohen \& Prusak, 2001), because it has become evident for many organizations that it is not possible to formalize every aspect of work into standard, predictable, mechanistic patterns that are easy to understand or recognize (Pelrine, 2011).

Forces like increasing globalization, a growing service sector, and the development of technology have made businesses seek new ways of working (Boxall \& Macky, 2009; Brown \& Eisenhard, 1997; D’Aveni, 1995) and new ways of improving their productivity (Kauhanen \& Maliranta, 2011; López-Cabrales, Pérez-Lunõ \& Valle-Cabrera, 2009; Appelbaum, Bailey, Berg \& Kalleberg, 2000; Barney \& Wright, 1998.) Management's most important contribution in the $21^{\text {st }}$ century is no longer the increase in productivity of the manual worker, but the increase in productivity of the knowledge worker. Work that requires new solutions, innovation, creativity, and interaction between people is often a poor fit with traditional industrial structures and management practices (Drucker, 1999).

The organizational environment is becoming volatile, uncertain, complex, and ambiguous (Bennet \& Lemoine, 2014). These kinds of environments demand flatter hierarchies, decentralization of decision-making, self-organization, empowerment of employees, and even the emergence and creation of a new order to create good conditions for highly productive ways of working (Pfeffer, 2016; Mitleton-Kelly, 2003; Edwards \& Wright, 2001; Daft \& Lewin, 1993). This change can be supported by stories, which can act as a powerful tool for change in organizations (Denning, 2002).

The rise of complexity theory, free agency, and the virtual workplace highlight the importance of social capital, and stories are the voice of social capital. They convey the norms, values, attitudes, and behaviors that define social groups. They show by example. (Cohen \& Prusak, 2001.) Stories are particularly relevant and effective in communicating complex knowledge in complex organizational situations (Sole \& Wilson, 2002) because stories have the power to convey complex ideas in simple forms (Snowden, 2000a; Snowden, 2003). 
The leadership power in knowledge-intensive organizations is not in an embodied person but in the meanings constructed in collective discursive interaction (Parry \& Hansen, 2007). Redefining organizational practices thus means moving away from mass production efficiencies, hierarchical organization, and central control towards flexible, learning organizations where leadership can be understood as a practice (Boje, Pullen, Rhodes, \& Rosile, 2011; Fairhurst, 2008), which emerges in organizational interaction, can be negotiated in communication, and manifests in everyday meaning construction (i.e., discourse) among organizational members (Auvinen, Riivari \& Sajasalo, 2018).

Every organization is a storytelling organization; a collective system in which the performance of stories is an essential part of sensemaking (Boje, 2008; Boje, 1991). Storytelling is not only natural for organizations; it is probably used more heavily than any other information channel (Reamy, 2002). Storytelling allows the swift and effective sharing and understanding of business information (Barker \& Gower, 2010) and describes complex issues, explains events, helps people to understand difficult changes, presents other perspectives, makes connections, and communicates experience (Wende, Philip \& Dubberke, 2009; Nielsen \& Madsen, 2006). Stories told in an organization reveal the ideation pattern of that organization (Snowden, 2003). This makes storytelling an excellent business tool in many organizational areas (Barker \& Gower, 2010), an essential leadership skill (Cohen \& Prusak, 2001), and a driver of productivity and business success. It has even been suggested that "people follow the story as much as they follow the storyteller or author, hence the story becomes the leader" (Parry \& Hansen, 2007).

Stories play an important role in imparting and storing organizational knowledge (Schreyögg \& Koch, 2005) because stories convey meaning and knowledge, not just mere information (Reamy, 2002). An organizational story is defined as a detailed narrative of past management actions, employee interactions, or other intra- or extra-organizational sequential events (Swap, Leonard, Shields \& Abrams, 2001) that evolve around actors (Nielsen \& Madsen, 2006). The many uses of stories include the creation of brand and partnerships, the storage and dissemination of organizational knowledge, and cultural change and empowerment in uncertain times (Snowden, 2000b).

There is no right way to tell a story (Denning, 2005) but much depends on the leader's ability to engage with employees and to use illustrations deliverable to a mass audience while, at the same time, retaining individual appeal. Being able to put the strategy into context by illustrating it with a simple, emotionally engaging narrative is far more powerful than traditional organizational communications (Love, 2008). In a decision-making situation, stories keep the organization from repeating historically bad choices or they can be used to invite the repetition of past successes (Boje, 1991). Storytelling is a way to connect people to the culture, values and ways people do things in an organization. In addition, people tend to trust organizations that have a calling beyond pure profitability (Cohen \& Prusak, 2001), and storytelling can help members of the organization feel connected to a larger community and a higher purpose (Driscoll $\&$ McKee, 2007). Story performances are part of an organization-wide information-processing network and stories construct an institutional memory system of the organization (Boje, 1991). To have the media to deliver the company's message and story is powerful and credible when compared to a situation where a company tries to deliver the message itself (Fog, Budtz, Munch \& Blanchette, 2010).

\section{DATA AND METHODOLOGY}

The data for the study was collected from published articles on Vincit between years 2012 and 2019 (Table 1) and two interviews that were conducted in 2012. The interviewees were two employees of the company and their purpose was to get a general understanding of the case company. The media data consists of 119 publications, 24 of which were released by the major Finnish national newspaper Helsingin Sanomat and six by the Finnish public service broadcasting company Yle. The rest of the publications appeared in local newspapers (11), financial papers and magazines (19) and professional magazines in different fields (11). Other companies and organizations account for 38 publications, and the number of official press releases was 10 .

Table 1: Description of data by sources

\begin{tabular}{|c|c|}
\hline Helsingin Sanomat & 24 \\
\hline Yle & 6 \\
\hline Other newspapers & 11 \\
\hline Financial papers \& magazines & 19 \\
\hline Other professional magazines & 11 \\
\hline Other companies and organizations & 38 \\
\hline Press releases & 10 \\
\hline Total & 119 \\
\hline
\end{tabular}


Narrative is said to be a fundamental way for humans to organize their understanding of the world (Cortazzi, 2001). Narrative research, which is usually qualitative by nature, aims to explore and conceptualize human experience and action as it is represented in textual form (Salkind, 2010), even though text research does not capture the basic aspects of the situated language performance because the focus is on textual content rather than the storytelling event (Boje, 1991).

Narrative research can take many approaches that rely on written or spoken words or even the visual representation of individuals. It thus allows many data collection methods. Narrative research usually focuses on the lives of individuals as told through their own stories. (Narrative research n.d.) Narratives capture both the individual and the context (Moen, 2006). A narrative research method can take an interpretive approach involving storytelling methodology where the story becomes an object of study, focusing on how individuals or groups make sense of events and actions in their lives (Mitchell \& Egudo, 2003).

In narrative analysis, the emphasis is on storied experience (Salkind, 2010) - typically what is narrated and how (Narrative research n.d.). In narrative analysis, researchers interpret stories and make conclusions by focusing on different elements, such as how the story is structured, what functions the story serves, what the substance of the story is, and how the story is performed (Allen, 2017; Cortazzi, 2001).

According to Poulton (2005), stories can be classified as 1) "You know the story, don't you?" (implying the listener knows the story and has full command of the storyline and its meaning), 2) the joke (punchline defined), 3) anecdotes (crystallized tales), 4) narratives of great length and dramatic zeal (epics, sagas, myths), 5) carefully constructed "stories" with public relations intent, and 6) simple recounting of events. There are thus variations in story type and use, but stories create clusters or chunks of information that make them easier to pay attention to and to remember (Reamy, 2002).

The essence of a story is to offer a streamlined and surrogate experience (Sole \& Wilson, 2002) where analysis is balanced with emotional intensity (Snowden, 2005). A story is a narrative that can be told in many ways (Poulton, 2005) and a good story combines the explicit with the tacit as well as the information with the emotion (Ruggles, 2002). It conveys a thought, a moral, or a consequence in a way that forces the listener to look at a common message in a new way (Poulton, 2005). The organization's use of a metaphor of itself is done to simplify a complex of events that make up the story. The metaphor and the causal narrative behind it become the basis for how individuals in organizations define who they are, what the organization is, and how the organization responds to conflict or chaos. A good organizational story includes 1) an inclusive approach; 2) emotional content; 3) relevance; 4) prospective value; 5) strong characters; 6) familiarization; and 7) promotion of trust (Poulton, 2005). The purpose of storytellers is to illustrate general truths that they expect the recipients to infer by implying rather than boldly stating the general truth (Nair, 2003). Most storytelling is done in conversation and involves the listeners as co-producers (Boje, 1991).

\section{RESULTS}

In this study, we investigated 119 articles published in public media over the course of eight years, i.e., between 2012 and 2019. In addition, two interviews carried out in 2012 were included in the data as they contained stories told verbally. Most of the articles published in the media were written so that each one of them included numerous narratives concerning different aspects of organizational life and it was not always clear to point out the main substance of the story. However, we chose the main theme on the basis of their title and analyzed the stories from three point of views: what the substance of the story is, what the function of the story is and how the stories are structured.

Our analysis started with substance, i.e., themes of published stories, because a theme of a story is an emergent property of anecdotes told in an organization. Identifying the pattern of themes provides insights into the reality of the organization's culture (Snowden, 2003). Also, stories select elements of the basis of importance and fit with other elements (Reamy, 2002). Categorized by the title and the main substance, the articles were classified thematically under nine different themes listed here in the order of occurrence frequency: 1) Wellbeing at work, 2) Profitability, 3) Management practices, 4) Good reputation, 5) Recruiting practices, 6) Bad reputation, 7) Payment policy, 8) Marketing, and 9) Goodwill. The results of this preliminary analysis are presented in quantitative measures. The themes are here followed by the respective number of articles and then described, giving examples of their titles (Table 2).

Table 2: Thematic classification of data

\begin{tabular}{|l|l|l|}
\hline $\begin{array}{l}\text { Wellbeing at } \\
\text { work }\end{array}$ & 27 & $\begin{array}{l}\text { IT company promises to make dreams come true (Helsingin Sanomat, 2014) } \\
\text { The result of the company may be eroded if employees feel bad (Helsingin Sanomat, 2014) } \\
\text { This is no hippie camp (Tuplaamo, 2015) } \\
\text { Cooperation is more important than ever - expert advice on how to become a nice colleague }\end{array}$ \\
\hline
\end{tabular}




\begin{tabular}{|c|c|c|}
\hline & & $\begin{array}{l}\text { (Helsingin Sanomat, 2016) } \\
\text { Welcome packages and free lunches - this is the first workday in a desirable work place } \\
\text { (Helsingin Sanomat, 2017) }\end{array}$ \\
\hline Profitability & 21 & $\begin{array}{l}\text { IT company Vincit Group gains a fast start on the stock exchange (Helsingin Sanomat, } \\
\text { 2016) } \\
\text { Vincit builds the grounds for future growth (Kauppalehti, 2018) }\end{array}$ \\
\hline $\begin{array}{l}\text { Management } \\
\text { practices }\end{array}$ & 18 & $\begin{array}{l}100 \text { employees, only two bosses (Helsingin Sanomat, 2014) } \\
\text { The CEO of Vincit: "I'm a bad boss" (Telma, 2015) } \\
\text { Rebel - why did rule-hater Mikko Kuitunen decide to list Vincit on stock? (Talouselämä, } \\
2016 \text { ) } \\
\text { One sentence written on a beer mat revolutionized Mikko Kuitunen's life - this is how he } \\
\text { became an IT millionaire who runs award-winning top company in a totally peculiar way } \\
\text { (Lapin Kansa, 2018) } \\
\text { "The one who makes most mistakes wins" - Finns do not dare to fail, say successful } \\
\text { business leaders, and give an example that saved hundreds of lives (Helsingin Sanomat, } \\
2018 \text { ) }\end{array}$ \\
\hline $\begin{array}{l}\text { Good } \\
\text { reputation }\end{array}$ & 14 & $\begin{array}{l}\text { Europe's best workplace: Vincit from Tampere (Yle, 2016) } \\
\text { Employer of Year } 2017 \text { - Vincit wins the competition (Tampereen kaupunki, 2018) } \\
\text { Vincit - an IT company that customers love (Joki, 2018) }\end{array}$ \\
\hline $\begin{array}{l}\text { Recruiting } \\
\text { practices }\end{array}$ & 11 & $\begin{array}{l}\text { One in } 100 \text { is hired (Helsingin Sanomat, 2012) } \\
\text { IT company wants more women in the business (Helsingin Sanomat, 2014) } \\
\text { IT company Vincit leads the reputation inquiry - the company pays 5,000 euros in } \\
\text { compensation to employees who are disappointed during their probation (Helsingin } \\
\text { Sanomat, 2017) }\end{array}$ \\
\hline $\begin{array}{l}\text { Bad } \\
\text { reputation }\end{array}$ & 10 & $\begin{array}{l}\text { A recruitment advertisement looking for "a better Mikko" chipped away at the reputation } \\
\text { and stock exchange price: Attention got expensive for Vincit (Kauppalehti, 2019) } \\
\text { IT company apologizes for its recruitment advertisement: Young women considered it } \\
\text { discriminatory (Yle, 2019) } \\
\text { A recruitment advertisement for a Finnish success company made Slush-generation young } \\
\text { people mad: "As a woman I do not feel like laughing" (Aamulehti, 2019) }\end{array}$ \\
\hline $\begin{array}{l}\text { Payment } \\
\text { policy }\end{array}$ & 7 & $\begin{array}{l}\text { In an IT company, everyone knows each other's salaries - envy did not increase (Helsingin } \\
\text { Sanomat, 2015) } \\
\text { What does open payment policy require? Software company Vincit is doing what others are } \\
\text { just talking about (Mandatum Life, 2017) } \\
\text { Open payment policy requires a lot more than just open payments (Mandatum Life, 2018) }\end{array}$ \\
\hline Marketing & 6 & $\begin{array}{l}\text { Two winners were awarded in the competition searching for the most marketing-spirited } \\
\text { engineer in } 2014 \text { (TEK verkkolehti, 2014) } \\
\text { Qualified workforce ran out in Tampere, Vincit is expanding its operations in Turku - and } \\
\text { searching for a team leader using local dialect (Aamulehti, 2017) } \\
\text { A stocklisted company slips ambiguous messages in official announcements - Did you } \\
\text { notice the spoonerism? (Aamulehti, 2018) }\end{array}$ \\
\hline Goodwill & 5 & $\begin{array}{l}\text { Giving up the immaterial rights of software does not prevent profitable business (Codento, } \\
\text { 2015) }\end{array}$ \\
\hline
\end{tabular}


Following the thematic classification of data, some of the narratives were chosen for closer scrutiny according to a criterion that there is some kind of structure for the story, usually a logical one, and that the story needs interpretation for understanding its meaning. These stories were scrutinized more closely and categorized according to Poulton's (2005) classification by structure into six categories (Table 3) to reveal the purpose the story serves.

Table 3: Analysis of narratives by purpose (according to Poulton, 2005)

1) "You know the story, don't you?" (implying the listener knows the story and has full command of the storyline and its meaning)

How can people then take the initiative? This is best described by a practice called "Gavel of the month". The practice has its roots in a coincidence. Mikko Kuitunen won a wooden gavel in a competition and nobody knew what use they could make of such an ugly item. Then someone suggested that they could hand on the gavel to an employee so that the employee would be entitled to take one decision concerning well-being at work. This way everybody in the company would get a chance to practice decision-taking in a very symbolic way. So, every month, somebody working for the company gets the gavel in their hands and takes a decision that will be realized automatically and without questioning. There is no budget, no rules, no instructions. The only limitation is that the decision must be such that it makes Vincit a better place to work for as many employees as possible. The person who has taken the decision chooses their follower for next month and hands on the gavel. (Parempi työelämä, 2015.)

2) The joke (punchline defined)

They wrote their one and only goal on a beer mat at a restaurant. It said: "One should not be pissed off when coming to work on Mondays." (Helsingin Sanomat, 2019.)

3) Anecdotes (crystallized tales)

The company emphasizes radical examples that arouse attention but at the same time they want to avoid falseness and cheap media attraction. However, a bold communication style is part of Vincit's style and the company is not afraid of someone disapproving of their way of expression. Mikko Kuitunen says: It is important to provoke. If nobody gets angry, nothing changes. (Telma, 2015)

4) Narratives of great length and dramatic zeal (epics, sagas, myths)

A year after the establishment of Vincit, the principles of the founders were tested. Mikko Kuitunen, one of the founders, realized he had made a huge mistake. He had established the company with loan money from the bank in order to be able to hire seven programmers. Their first customer was a big American company and it never occurred to them that it would have been good to have other customers too. When the big American company issued a profit warning, they found themselves in a typical death valley of start-ups; they had an empty order book and a big bank loan. At that time, they had ten employees who could, of course, have gone elsewhere, but finally, everybody sat down on a sofa and said how much salary they needed to survive everyday life. Kuitunen himself took half of his salary and put in 16 hours per day. Everybody in the company started to sell. The openness paid off. Nobody resigned and in half a year, they had found enough new customers to go on (Helsingin Sanomat, 2014).

5) Carefully constructed "stories" with public relations intent

The name Vincit is from the Latin phrase amor vincit omnia and labor omnia vincit. Those working for Vincit believe that love of hard work and hard work as such are the features that make them distinctive in a way that makes them characterize themselves as a software company that changes the management of the future (Telma, 2015).

6) Simple recounting of events

The employees participate in recruiting their colleagues. The company uses a recruiting guarantee. It means that anybody who sends an application will get a response within twenty-four hours. To gain an insight into what this means: the company gets about 700 applications per year and in 2014, they recruited 52 new employees. When recruiting they want to be sure that it is possible for the prospective employee to fulfill their dreams in the organization, and if not, they will not be hired no matter how good a programmer they are. The whole business depends on people, on their personal skills and 
team skills. Since the differences in productivity of software designers is huge, it is vital that the right people are recruited (Telma, 2015).

Then some stories were analyzed in more detail using Poulton's (2005) characterizations of a good organizational story (Table 4) reveal the internal structure of an organizational story. The following narrative was captured in one of the interviews included in the data. The interviewee was an employer of the company.

Table 4: Analysis of narratives by structure (according to Poulton, 2005)

\begin{tabular}{|l|l|}
\hline In 2011, Vincit lost a big customer again and this time, & 1) an inclusive approach \\
\hline $\begin{array}{l}\text { one-third of their personnel found themselves without a project. } \\
\begin{array}{l}\text { A concept of 'Battle Plan' was created. The idea of the 'Battle Plan' is such that if } \\
\text { something unexpected happens, it is described as a battle where there are coordinated } \\
\text { troops that attack on the battlefront one after another. }\end{array}\end{array}$ & 3) relevance \\
\hline $\begin{array}{l}\text { Everybody started looking for new leads } \\
\text { by going through their own personal networks, finding people that could be prospective } \\
\text { customers and passing this information to the sales team. }\end{array}$ & 4) prospective value \\
\hline $\begin{array}{l}\text { The excitement in the battle grew } \\
\text { and finally, 2011 was financially better than the previous year even though they had lost } \\
\text { one big customer that accounted for almost a half of their turnover. (Interview, 2012) }\end{array}$ & 7) promotion of trust \\
\hline
\end{tabular}

\section{CONCLUSIONS}

The well-being at work theme (27 times) was the most common theme in public media delivered stories of the company. The company became mentioned quite often also because of its profitable operations (21 times) or because of its management practices (18 times). Stories about their general good reputation (14 times), recruiting practices (11 times) and bad reputation (10 times) were also moderately common. The payment policy (7 times), marketing (6 times) and goodwill ( 5 times) were the least common themes. Of the above-mentioned themes, the well-being at work, management practices and recruiting practices are themes that the company has advocated in public from its very beginning. On the other hand, stories about profitability and good reputation are usually generated by press in their search for explanations of the company's success or because there is always common interest for financially sound companies. It is also worth of noting that the stories about the company's bad reputation are all linked to one incident linked with a very unsuccessful wording in a recruiting advertisement.

Following Poulton's (2005) classification: 1) "You know the story, don't you?" (implying the listener knows the story and has full command of the storyline and its meaning), 2) the joke (punchline defined), 3) anecdotes (crystallized tales), 4) narratives of great length and dramatic zeal (epics, sagas, myths), 5) carefully constructed "stories" with public relations intent, and 6) simple recounting of events, it was possible to find a purpose for each story. These stories are used as type stories which, when stuck together, form a whole storyline for the organization they describe. However, a model or type story is always an idealization, and in real life situations its elements appear in different ways depending on the situation, the teller of the story and the target audience.

The stories were also analyzed by the internal structure of the story into seven elements: 1) an inclusive approach; 2) emotional content; 3) relevance; 4) prospective value; 5) strong characters; 6) familiarization; and 7) promotion of trust. This analysis reveals that it is possible to recognize some model stories with these elements. The model stories often contain a lesson or a procedure that helps the members of the organization to interpret situations and act accordingly. The stories, repeated both inside the organization and through media, contain something essential about the organization. They help in creating collective identity and underline the basic principles of the organization's life in a manner that is easy to understand and remember if compared to mainstream, often obscure organizational language. 


\section{DISCUSSION}

Vincit is a knowledge-intensive information technology organization where the power (very decentralized) is constructed in meanings by collective discursive interaction (Parry \& Hansen, 2007) and where leadership can be understood as a practice (Fairhurst, 2008; Boje, Pullen, Rhodes, \& Rosile, 2011) emerging in interaction. In Vincit, this is manifested by highlighting the two most common themes in their organizational stories: well-being at work and management practices. These themes are intertwined and they define the organizational culture and values of the company to the point that they have established their own leadership practice called LaaS (Leadership as a Service), a service that they sell to other companies.

Storytelling is an essential leadership skill (Cohen \& Prusak, 2001) and a powerful tool because a lot of empirical evidence of an organization's life is in the form of stories told in the organization. The stories show that not only are the themes appealing, but also the purposes and the inner structures of the stories (Poulton 2005) are skillfully constructed so that the stories can act the driver of productivity and business success. Both themes are important in the company's official storyline conveyed by the press. This has been evidenced in Vincit year after year as the company has grown in size and reputation and has succeeded economically while being able to stick to its two main goals: more satisfied employees and more satisfied customers every day. Officially, Vincit claims that there are only two factors behind their success: satisfied customers and employees, and this view is supported by a range of stories emphasizing well-being at work, original recruiting practices, and the good reputation the company enjoys among information technology jobseekers and the wider public.

People who are more skilled storytellers seem to be more effective communicators in organizations (Boje, 1991). The leader of Vincit has been able to engage with employees and use skillfully constructed stories and illustrations deliverable to a mass audience in a way that preserves the narrator's voice, even in written texts (Poulton, 2005) delivered by media. Also, the strategy has been put into context by illustrating it with simple, emotionally engaging narratives (Love, 2008) and supported with visual work that made every individuals' dreams visible (by a visual artist who realized the dreams as pictures) and changed the strategy process into a dream process called Utopia.

For a company having no traditional strategy, vision, mission, or values (and, officially, a no-policy policy), storytelling is a way to connect people to the culture, tacit knowledge, norms, values, and ways people do things in the organization (Cohen \& Prusak, 2001) in a very powerful way that makes people trust the organization they work for and create a feeling that they, indeed, have a calling (Driscoll \& McKee, 2007) beyond pure profitability, which theme was mainly emphasized by media but not raised by the company itself. Stories act as a repository of collective wisdom because it is through the story or narrative that people literally come to "know", i.e., construct and maintain knowledge of the organization (Pradl, 1984). They help the organization make sense of its past and to foresee its possible futures, to construct organizational identity, to familiarized new employees and to find not only customers but also other companies to cooperate with.

Vincit has been able to use metaphors of itself and causal narratives to define who they are, what the organization is, and even how the organization responds to conflict or chaos. In addition, they have had the media to deliver the company's story in a powerful and credible manner (Fog, Budtz, Munch \& Blanchette, 2010) despite a couple of overkills that highlight the fact that a story, to succeed, is very dependent on the shared background of the audience (Denning, 2002). Over the course of time, different stories told at different occasions form a narrative of a company that conveys the message it wants to tell others and allows listeners access to the organization's implicit culture, values, and social knowledge.

The results of this study are based on deductive analysis that was made using the existing theory. The theory gives structural elements of an ideal model of a story and classification for its purposes. However, the results of this study only describe one case company and are not generalizable, i.e., the way how Vincit uses organizational stories is not copyable to any other organizations, not even similar knowledge intensive information technology companies, or even easily replicable. This study reveals qualities of group experience in the forms of stories in one organization, and helps determining questions and types of follow-up research, such as closer scrutiny on the connections of storytelling and productivity or business success.

\section{REFERENCES}

[1] Allen, M. (2017) Narrative analysis. The Sage Encyclopedia of Communication Research Methods. Retrieved March 4, 2020, from https://methods.sagepub.com/reference/the-sage-encyclopedia-of-communication-researchmethods/i9374.xml.Author1_Name, Author2_Name, "Paper Title ACASH: An Adaptive Web Caching method based on the Heterogeneity of Reference Characteristics", Journal of AICIT, AICIT(Publication_Name), vol. 10, no. 4, pp.169-711, 2015.

[2] Alvesson, M. (2001). Knowledge Work: Ambiguity, Image and Identity. Human Relations, 54, 863-886. 
[3] Appelbaum, E, Bailey, T., Berg, P. \& Kalleberg, A. (2000). Manufacturing Advantage: Why High-Performance Work Systems Pay Off. Ithaca: ILR Press.Author1_Name, Author2_Name, Web Caching and Replication, AddisonWesley (Publication__Name), USA, 2014

[4] Author1_Name, Author2_Name, "Exploring the bounds of Web latency reduction from caching and prefetching", In Proceeding(s) of the AICIT Symposium (Conference) on Internet Technologies, pp.13-22, 2009.

[5] Auvinen, T., Riivari, E.\& Sajasalo, P. (2018). Lessons Learned from Traditional and "New-Age" Leadership in A. Eskola (Ed.), Navigating Through Changing Times - Knowledge Work in Complex Environments. New York: Routledge.

[6] Bandura, A. (2002). Growing primacy of human agency in adaptation and change in the electronic era. European Psychologist 7(1), 2-16. Retrieved May 24, 2020 from http://www.uky.edu/ eushe2/Bandura/Bandura2002EP.pdf.

[7] Barker, R. \& Gower, K. (2010). Strategic Application of Storytelling in Organizations. Toward Effective Communication in a Diverse World. Journal of Business Communication, 47(3), 295-312. Retrieved May 21, from http://www.dea.univr.it/documenti/Avviso/all/all886336.pdf.

[8] Barney, J. \& Wright, P. (1998). On Becoming a Strategic Partner: The Role of Human Resources in Gaining Competitive Advantage. Human Resource Management 37(1), 31-47. Retrieved February 7, 2020, from http://digitalcommons.ilr.cornell.edu/cgi/viewcontent.cgi?article=1149\&context=cahrswp.

[9] Bennet, N. \& Lemoine, J. (2014). What VUCA Really Means for You. Harvard Business Review 92(1/2), 27.

[10] Boje, D. (1991) The Storytelling Organization: A Study of Story Performance in an Office-Supply Firm. Administrative Science Quarterly, 31(1), 106-126. Retrieved May 14, 2020, from

https://www.researchgate.net/publication/221931928_The_Storytelling_Organization_A_Study_of_Story_Performa nce_in_an_Office-Supply_Firm.

[11]Boje, D. (1999). Storytelling leaders. Retrieved February 8, 2020, from http://business.nmsu.edu/ dboje/leaders.html.

[12] Boje, D., Pullen, A. Rhodes, C. \& Rosile, G. (2011). The virtual leader. In A. Bryman, D. Collinson, K, Grint, B. Jackson and M. Uhl-Bien (Eds.), Sage Handbook of Leadership, 518-29. London: Sage.

[13] Brown, S., \& Eisenhardt, K. (1997). The art of continuous change: linking complexity theory and time-paced evolution in relentlessly shifting environments. Administrative Science Quarterly 42(1), 1-34.

[14] Cappelli, P. \& Neumark, D. (2001). Do "high performance" work practices improve establishment level outcomes? Industrial and Labor Relations Review 54, 737-76. Retrieved February 7, 2020, from https://www.researchgate.net/publication/5195348_Do_High_Performance_Work_Practices_Improve_Establishmen t-Level_Outcomes.

[15] Cohen, D. \& Prusak, L. (2001) How Social Capital Makes Organizations Work - In Good Company. Concentrated Knowledge for the Busy Executive, 23(8). Retrieved February 7, 2020, from http://www.cognitionnet.com/member/resources/Summaries/Personnel_HR/In_Good_Company.pdf.

[16] Constable, R., Cowell, M., Crawford, S., Golden, D., Hartvigsen, J., Morgan, K., Mudgett, A., Parrish, K., Thomas, L., Thompson, E., Turner, R. \& Palmquist, M. (2005). Ethnography, Observational Research, and Narrative Inquiry. Writing@CSU. Colorado State University Department of English. Retrieved December 12, 2020, from Commentary on Ethnography, Observational Research, and Narrative Inquiry (colostate.edu).

[17] Cortazzi, M. (2001) Narrative analysis in ethnography, In P. Atkinson (ed), Handbook of Ethnography, London, Sage, 384-394.

[18] Daft, R. \& Lewin, A. (1993). Where are the Theories for the "New" Organizational Forms? An Editorial Essay. Organization Science 4(4), 513.

[19] D'Aveni, R. 1995. Hypercompetitive Rivalries. New York: Free Press.

[20] Denning, S. (2002). The Narrative Lens: Storytelling in 21st Century Organizations. Knowledge Directions, 3(2), 92-101. Retrieved May 14, 2020, from http://www.providersedge.com/docs/km_articles/using_stories_to_spark_organizational_change.pdf.

[21] Denning, S. (2005). The Leader's Guide to Storytelling: Mastering the Art and Discipline of Business Narrative. San Francisco: Jossey-Bass.

[22] Driscoll, C., McKee, M. (2007). Restorying a Culture of Ethical and Spiritual Values: A Role for Leader Storytelling. Journal of Business Ethics, 73, 205-217. 
[23] Drucker, P. (1999). Knowledge-Worker Productivity. The Biggest Challenge. California Management Review 41(2), 79-94. Retrieved February 7, 2020, from

http://forschungsnetzwerk.at/downloadpub/knowledge_workers_the_biggest_challenge.pdf.

[24] Edwards, P. \& Wright, M. (2001). High-involvement work systems and performance outcomes: The strength of variable, contingent and context-bound relationships. International Journal of Human Resource Management 12(4), $568-85$.

[25] Fairhurst, G. (2008). Discursive leadership: a communication alternative to leadership psychology. Management Communication Quarterly 21(4), 510-21.

[26] Felluga, Dino, 2003. Introduction to Narratology. Introductory Guide to Critical Theory. Purdue University. Retrieved December 12, 2020 from General Introduction to Narratology (purdue.edu).

[27]Fog, K., Budtz C., Munch P. \& Blanchette S. (2010). Storytelling. Branding in Practice. Berlin, Heidelberg: Springer.

[28] Gabriel, Y. (2000). Storytelling in organizations: Facts, Fictions, Fantasies. Oxford: Oxford University Press.

[29] Gallicano, T. (2009). Personal Relationship Strategies and Outcomes in a Membership Organisation. Journal of Communication Management, 13(4), 310-328.

[30] Gill, R. (2011), Corporate Storytelling as an Effective Internal Public Relations Strategy. International Business and Management, 3(1), 17-25. Retrieved May 24, 2020, from http://www.cscanada.net/index.php/ibm/article/viewFile/j.ibm.1923842820110301.107/1810.

[31] Hannabuss, S. (2000). Narrative knowledge: eliciting organisational knowledge from storytelling. Aslib Proceedings, 52(10), 402-413. Retrieved May 2, 2020 from https://www.deepdyve.com/lp/emerald-publishing/narrativeknowledge-eliciting-organisational-knowledge-from-IkT4zn4njS.

[32] Howell, J. 1(997). Substitutes for leadership: their meaning and measurement - An historical assessment. Leadership Quarterly 8(2), 113-16. Retrieved February 8, 2020, from doi: 10.1016/S1048-9843(97)90011-4.

[33] Kauhanen, A. \& Maliranta, M. (2011). Terve tuho - tietä tuottaville työpaikoilla ja kasvulle. EVA analyysi, no. 14. Retrieved May 2, 2020, from http://www.eva.fi/wp-content/uploads/2011/03/Terve-tuho.pdf.

[34] Kerr, S. \& Jermier, J. (1978). Substitutes for leadership: their meaning and measurement. Organizational Behavior and Human Performance, 22(3), 375-403.

[35] Knotts, R., \& Thibodeaux, M. (1992). Verbal skills in cross-culture managerial communication. European Business Review, 92(2), v-vii.

[36] López-Cabrales, A., Pérez-Lunõ, A. \& Valle-Cabrera, R. (2009). Knowledge as a mediator between HRM practices and innovative activity. Human Resource Management 48, 485-503. Retrieved February 7, 2020, from doi: 10.1002/hrm.2095.

[37] Love, H. (2008). Unraveling the technique of storytelling. SCM 12(4), 24-27. Retrieved February 7, 2020, from http://www.nickihayes.com/wp-content/portfolio/scm-storytelling.pdf.

[38] Madlock, P. (2008). The Link Between Leadership Style, Communicator Competence, and Employee Satisfaction. Journal of Business Communication, 45(1), 61-78. Retrieved May 2, 2020 from https://www.researchgate.net/publication/238335958_The_Link_Between_Leadership_Style_Communicator_Comp etence_and_Employee_Satisfaction.

[39] Marchiori, M. \& Bulgacov, S. (2012). Strategy as communicational practice in organizations. International Journal of Strategic Communication 6(3), 199-211.

[40] McCarthy, J. (2008). Short Stories at Work: Storytelling as an Indicator of Organizational Commitment. Group \& Organization Management, 33 (2), 163-193.

[41] McDaniel, R. Jr., \& Driebe, D. (200)5. Uncertainty and Surprise: An Introduction. In R. Reuben, D. Driebe (Eds.), Uncertainty and Surprise in Complex Systems: Questions on Working with the Unexpected. Berlin: Springer.

[42] Mitchell, M. \& Egudo, M. (2003) A Review of Narrative Methodology. Retrieved March 4, 2020, from https://www.webpages.uidaho.edu/css506/506\%20readings/review\%20of\%20narritive\%20methodology\%20australi an\%20gov.pdf.

[43] Mitleton-Kelly, E. (2003). Complex Systems and Evolutionary Perspectives on Organisations: The Application of Complexity Theory to Organisations. Oxford: Pergamon. 
[44] Moen, T. (2006). Reflections on the Narrative Research Approach. International Journal of Qualitative Methods, 5(4), 56-69. Retrieved May 24, 2020, from https://aisel.aisnet.org/cgi/viewcontent.cgi?referer=\&httpsredir=1\&article=1077\&context=jitta.

[45] Morgan, G. (2006). Images of Organization. Thousand Oaks, California: SAGE Publications.

[46] Nair, R. (2002) Narrative Gravity: Conversation, Cognition, Culture. New York: Routledge.

[47] Narrative research. What is Narrative Research? Atlas.ti. Retrieved May 20, 2020, from https://atlasti.com/narrativeresearch/.

[48] Nielsen, L. \& Madsen, S. (2006). Using storytelling to reflect on IT projects. Journal of Information Theory and Application, 7(4), 35-47. Retrieved May 4, 2020, from https://aisel.aisnet.org/cgi/viewcontent.cgi?referer=https://www.bing.com/\&httpsredir=1\&article=1077\&context=jitt a.

[49] Nonaka, I. (1994). A dynamic theory of organizational knowledge creation. Organization Science, 5(1), 14-37. Retrieved May 4, 2020, from http://www.uky.edu/ gmswan3/575/Nonaka_1994.pdf.

[50] Parry, K. \& Hansen, H. (2007). Organizational Story as Leadership. Leadership 3(3), 281-300.

[51] Pelrine, J. (2011). On Understanding Software Agility - A Social Complexity Point of View. E:CO Issue 13(1-2), 2637. Retrieved February 8 from http://cognitive-edge.com/articles/on-understanding-software-agility-a-socialcomplexity-point-of-view/.

[52] Pfeffer, J. (2016). Tell me lies, tell me sweet little lies: The many positive functions of being untruthful. People \& Strategy 39(4), 32-5. Retrieved May 20, 2020, from

https://www.thefreelibrary.com/Tell+me+lies\%2C+tell+me+sweet+little+lies\%3A+the+many+positive+functions...a0467681172.

[53] Pina e Cunha, M. (2002). The Best Place to be: Managing Control and Employee Loyalty in a Knowledge-Intensive Company. Journal of Applied Behavioural Science, 38(4), 481-495.

[54] Plowman, D., Solansky, S, Beck, T., Baker, L., Kulkarni, M. \& Travis. D. (2007). The role of leadership in emergent, self-organization. Leadership Quarterly, 18(4), 341-56. Retrieved February 7, 2020, from doi: 10.1016/j.leaqua.2007.04.004.

[55] Post, J. (2004). Governance and the Stakeholder Corporation: New Challenges for Global Business. Corporate Public Affairs, 14(2), 10-16.

[56] Pradl, G. (1984). Narratology: The Study of Story Structure. ERIC Digest. ERIC Clearinghouse on Reading and Communication Skills. Retrieved December 12, 2020, from https://www.ericdigests.org/pre-921/story.htm.

[57] Poulton, M. (2005). Organizational Storytelling, Ethics and Morality: How Stories Frame Limits of Behavior in Organizations. Electronic Journal of Business Ethics and Organization Studies, 10(2), 4-9. Retrieved February 7 , 2020, from http://ejbo.jyu.fi/pdf/ejbo_vol10_no2_pages_4-9.pdf.

[58] Reamy, T. (2002). Imparting knowledge through storytelling. KMWorld, 11(7). Retrieved May 24, 2020, from http://www.providersedge.com/docs/km_articles/Imparting_Knowledge_Through_Storytelling.pdf.

[59]Ruggles, R. (2002). The Role of Stories in Knowledge Management.Journal of Storytelling and Business Excellence. Retrieved May 14, 2020, from http://www.providersedge.com/docs/km_articles/The_Role_of_Stories_in_KM.pdf.

[60] Salkind, N. (2010). Encyclopedia of Research Design. Retrieved March 4, 2020, from https://methods.sagepub.com/reference/encyc-of-research-design/n259.xml.

[61] Savita, K., Hazwani, H. \& Kalid, K. (2011). The Development of a Narrative Management System: Storytelling in Knowledge Management. World Academy of Science, Engineering and Technology, 51. Retrieved May 22, 2020, from http://citeseerx.ist.psu.edu/viewdoc/download?doi=10.1.1.309.721\&rep=rep1\&type=pdf.

[62] Schreyögg, G. \& Koch, J. (2005). Knowledge Management and Narratives - Organizational effectiveness through storytelling. Erich Schmidt Verlag: Berlin.

[63] Snowden, D. (2000a). New Wine in Old Wineskins: From Organic to Complex Knowledge Management Through the Use of Story. Emergence, 2(4), 50-64. Retrieved May 2, 2020, from https://journal.emergentpublications.com/article/new-wine-in-old-wineskins/.

[64] Snowden, D. (2000b). The Art and Science of Story or “Are you sitting uncomfortably?" Business Information Review, 17(3), 147-156. Retrieved May 24, 2020, from 
https://www.researchgate.net/publication/247759340_The_art_and_science_of_Story_or_\%27Are_you_sitting_unco mfortably\% 27.

[65] Snowden, D. (2002). Narrative Patterns: Uses of Story in the Third Age of Knowledge Management. Journal of Information and Knowledge Management, 1(1), 1-6.

[66] Snowden, D. (2003). Narrative Patterns, the perils and possibilities of using story in organisations. Oxford University Press. Retrieved May 2, 2020, from http://old.cognitive-edge.com/wp-content/uploads/2001/01/41narrative-patterns---perils-and-possibilities-final.pdf.

[67] Sohlberg, P., Czaplicka M., Lindblad, S., Houtsonen, J. Müller, J. \& Morgan, M. (2007). Professional expertise under restructuring: comparative studies of education and health care. Retrieved February 8, 2020, from http://www.gu.se/digitalAssets/1321/1321780_profknow_wp3.pdf.

[68] Sole, D. \& Wilson, D. (2002). Storytelling in Organizations: The power and traps of using stories to share knowledge in organizations. Retrieved May 11, 2020, from http://www.providersedge.com/docs/km_articles/Storytelling_in_Organizations.pdf.

[69] Swap, W., Leonard, D., Shields, M. \& Abrams, L. (2001). Using Mentoring and Storytelling to Transfer Knowledge in the Workplace. Journal of Management Information Systems, 18, 95-114.

[70] Uhl-Bien, M., Russ, M. \& McKelvey, B. (2007). Complexity Leadership Theory: Shifting leadership from the industrial age to the knowledge era. The Leadership Quarterly 18(4), 298-318. Retrieved February 7, 2020, from https://digitalcommons.unl.edu/cgi/viewcontent.cgi?article=1017\&context=leadershipfacpub.

[71] Vendel $\varnothing$, M. (1998). Narrating Corporate Reputation. Becoming Legitimate through Storytelling. International Studies of Management \& Organization, 28(3), 120-137. Retrieved May 7, 2020, from https://www.researchgate.net/publication/235665786_Narrating_Corporate_Reputation_Becoming_Legitimate_Thro ugh_Storytelling.

[72] Wende, E., Philip, T. \& Dubberke, S. (2009). Storytelling - an instrument to bolster knowledge transfer in offshore software projects. Retrieved May 22, 2020, from http://citeseerx.ist.psu.edu/viewdoc/download?doi=10.1.1.468.3898\&rep=rep1\&type=pdf. 